ppi $201502 Z U 4645$

Esta publicación científica en formato digital es continuidad de la revista impresa ISSN-Versión Impresa 0798-1406 / ISSN-Versión on line 2542-3185Depósito legal pp $197402 Z$ U34
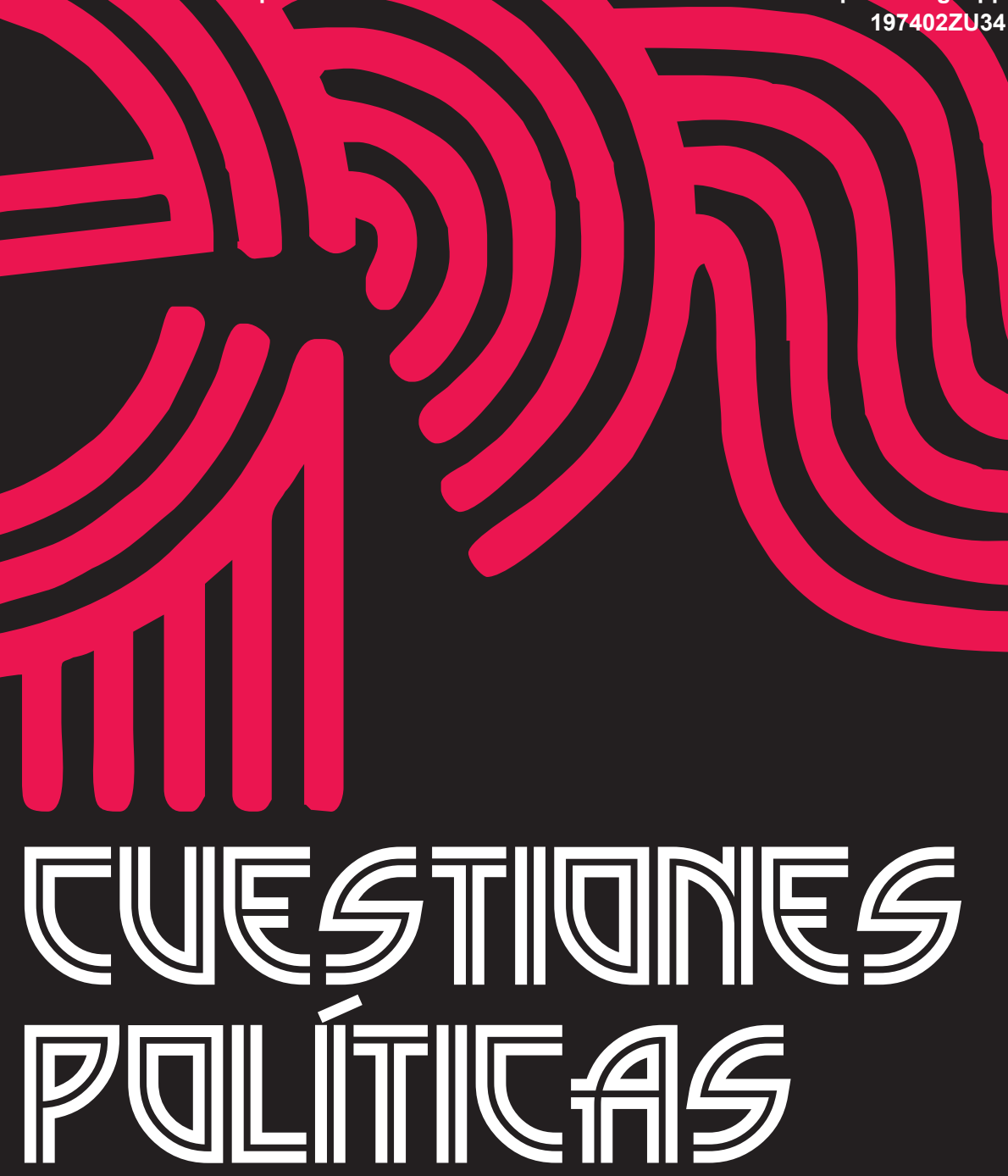

Instituto de Estudios Políticos y Derecho Público "Dr. Humberto J. La Roche" de la Facultad de Ciencias Jurídicas y Políticas de la Universidad del Zulia Maracaibo, Venezuela
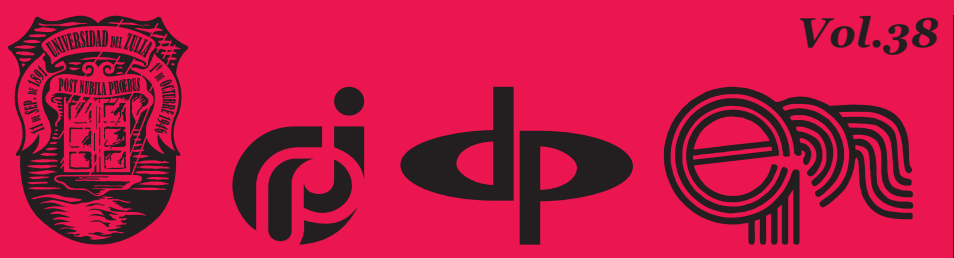

$N^{\circ}$ Especial 2da Parte 2020 


\title{
Information technology in the litigation due to the pandemic COVID-19
}

\author{
DOI: https://doi.org/10.46398/cuestpol.382e.37
}

\begin{abstract}
Nana Bakaianova *
Yurii Polianskyi **

Oleksii Svyda
\end{abstract}

\begin{abstract}
Changes in IT information technologies in the judiciary have become particularly evident in the context of the pandemic in an urgent need to file documents electronically, hold online court hearings, and the need to respond and efforts to ensure justice are imposed. In view of this, it is important to analyze the location and importance of information technologies in the judiciary in the face of the COVID-19 pandemic, in order to pay attention to the shortcomings and prospects of their implementation. As a result, the work aims to study the location and importance of information technology in the judiciary in the context of COVID-19. The research methods used are the dialectical, statistical method, method give method, method of a legal analysis document, articles and monographs, generalization method, comparison method, synthesis method, modeling method. By way of conclusion, the scope and significance of information technologies in the judiciary in a pandemic such as this one is highlighted, although their widespread use leads to problems in the courts that require
\end{abstract} other investigations for effective resolution.

Keywords: COVID-19; electronic court; information's technology; digital justice; legal informatics.

\footnotetext{
* Doctor of Juridical Science, Professor Assistant, Head of Department of Organization of Judicial, Law Enforcement Agencies and the Bar of National University «Odesa Law Academy», attorney, member of the Scientific Advisory Board of the National Association of Lawyers of Ukraine. ORCID ID: https:// orcid.org/oooo-0002-7669-0576. Email: 7777735@ukr.net

** Ph. D., Professor, Professor of Department of Organization of Judicial, Law Enforcement Agencies and the Bar of National University «Odesa Law Academy», Honored Lawyer of Ukraine. ORCID ID: https://orcid.org/oooo-0oo3-2469-9031. Email: polyansky@ukr.net

*** Ph. D., Professor Assistant of Department of Organization of Judicial, Law Enforcement Agencies and the Bar of National University «Odesa Law Academy», attorney. ORCID ID: https://orcid.org/ooooo002-5805-3557. Email: svida-alexey@ukr.net
} 


\section{Tecnologías de la información en el litigio en el contexto de la pandemia COVID-19}

\section{Resumen}

Los cambios en las tecnologías de la información TI en el poder judicial se han vuelto particularmente evidentes en el contexto de la pandemia cuando existe una necesidad urgente de presentar documentos electrónicamente, realizar audiencias judiciales en línea y se impone la necesidad de responder rápidamente y coordinar esfuerzos para garantizar el acceso a la justicia. Ante esto, es importante analizar el lugar y la importancia de las tecnologías de la información en el Poder Judicial ante la pandemia de COVID-19, para prestar atención a las deficiencias y perspectivas de su implementación. En consecuencia, el trabajo tiene como objetivo estudiar el lugar y la importancia de la tecnología de la información en el poder judicial en el contexto del COVID-19. Los métodos de investigación empleados fueron el método dialéctico, método estadístico, método analítico, método de análisis de documentos legales, artículos y monografías, método de generalización, método de comparación, método de síntesis, método de modelado. A modo de conclusión se destaca el alcance y significación de las tecnologías de la información en el poder judicial en una pandemia como la presente, aunque su uso generalizado acarrea cuestiones problemáticas en los tribunales que requieren de otras investigaciones para su resolución efectiva.

Palabras clave: COVID-19; tribunal electrónico; tecnologías de la información; justicia digital; informática jurídica.

\section{Introduction}

In today's context of the spread of coronavirus disease, the use of information technology in the courts is an urgent need. Thus, the information support of courts contributes to the observance of the main principles of justice - publicity and openness, which is very important in terms of restricting participation in court hearings, the inability to submit documents in person, etc.

Thus, the Law of Ukraine "On Protection of the Population from Infectious Diseases" (2000) (with the amendments (2020) regulates the effect of the quarantine and the possibility of establishing temporary restrictions on the rights of individuals and legal entities. Resolution of the Cabinet of Ministers of Ukraine No 211 of March 11, 2020 "On prevention of the spread of coronavirus Covid-19 on the territory of Ukraine" (with further changes) establishes quarantine on the territory of Ukraine (Venice 
Commission - Observatory on emergency situations, 2020; Hrevtsova, 2020).

On March 16, the Chairman of the Council of Judges of Ukraine (2020) addressed the courts with a recommendation to establish a special regime of courts. The High Council of Justice also provided recommendations to the courts on the administration of justice on March 26, 2020, and recommended: continuous administration of urgent cases, which are determined by procedural codes and courts (judges); if possible, to hold court hearings in real-time via the Internet; restrict access to court hearings of persons who are not participants in the proceedings; go to the processing of electronic correspondence. That is, in a pandemic, information technology must be used in the courts.

Requirements for the use of information technology in the courts of Ukraine meet international standards. Article 9 of the Constitution of Ukraine (1996) stipulates that the Convention for the Protection of Human Rights and Fundamental Freedoms, ratified by Ukraine, is part of national legislation. The Convention (1950) derogates from certain rights, but only to the extent required by the provision, and provided that such measures do not conflict with its other obligations under international law. Article 6 of the Convention for the Protection of Human Rights and Fundamental Freedoms also guarantees the right to a fair trial. Therefore, to fulfill its obligations under international law, Ukraine must ensure the right to a fair trial, and without the use of electronic technology, this is impossible.

Besides, Ukraine's accession to the European Union is impossible without the introduction of international standards for the exchange of legal information in electronic form via the Internet. Given the above, there is a topic about the role and place of information technology in the judiciary during a pandemic is quite relevant and requires detailed analysis.

\section{Analysis of recent research}

The regulation of artificial intelligence is of interest to many Ukrainian and foreign researchers, but there is no comprehensive study of international legal regulation of intellectual property rights created by artificial intelligence.

To study the place of information technology in justice in a pandemic, the works of the following authors were analyzed: Babyak (2016), Vaivala (2016), Grygorenko (2020), Yeltsov (2020), Zaporozhchenko (2020), Petrenko (2018), Moroz (2020), Fisun and Kostrikova (2020), Turkina (2011). Thus, Babyak (2016) in their article they analyzed the state and problems of information and analytical support of the administrative courts 
of Ukraine. The author drew attention to the fact that in the administrative courts at present the processes of informatization of both internal processes between courts are insufficiently established, and access to "e-justice" for participants in the process is not provided.

Further, Vaivala (2016) also devoted his research to communications and information technology of communications between the court and participants in the trial, between the court and other government agencies. Thus, the author analyzed in detail how to speed up the process of establishing a dialogue between the participants in the process and the court, as well as between the judiciary and government agencies to timely consider cases. The author's article was especially useful for the study of information technology in the judiciary in a pandemic.

What is more, Grygorenko (2020) analyzed the functioning of the subsystem "Electronic Court" and the court in video conferencing and addressed the problematic aspects of its functioning in a pandemic. In his work, Yeltsov (2020) revealed the essence of information support of courts. Moreover, Zaporozhchenko (2020) conducted a detailed analysis of the proceedings during quarantine and analyzed the case law on procedural issues. In addition, Moroz (2020) identified information support in the courts of Ukraine as the object of research of his work. The author analyzed in detail the state of information support in courts of different jurisdictions and put forward proposals to improve such support.

Besides, Petrenko (2018) analyzed the role of information technology in the judiciary, while earlier Turkina (2011) also analyzed the importance of the use of information technology in the judiciary.

Finally, Fisun and Kostrikova (2020) analyzed the quarantine proceedings and technologies that were introduced in the pandemic, as well as compared Ukrainian information technologies in justice with foreign ones. In addition, articles of lawyers on Internet resources, forums, websites of the High Council of Justice and other resources were analyzed, which allowed to conduct a comprehensive comprehensive study.

Thus, the analysis of the above literature shows that the study of information technology in the judiciary is of considerable interest among scientists. However, in a pandemic, no comprehensive study on this issue has been conducted. Therefore, there is an urgent need to study the place and role of information technology in justice in a pandemic. 


\section{Methodology}

During the study of the role of information technology in the judiciary in a pandemic, such methods as the dialectical method, statistical method, analytical method, method of analysis of legal documents, articles and monographs, generalization method, comparison method, synthesis method, and modeling method were used.

The dialectical method allowed to analyze how the legislation regulating the use of information technologies in normal conditions and how it has changed in quarantine conditions is developing. The statistical method allowed to analyze statistical data, compare them and compare the increase and decrease in the use of information technology in courts, and also allowed to analyze the reports of the State Judicial Administration of Ukraine (2018) and pay attention to mathematical indicators of information and technical support of courts, the state of the introduction of video communication in court premises, etc.

The analytical method made it possible to consider in detail the regulations of both international and Ukrainian and highlight their main provisions governing the introduction of e-court in Ukraine. The method of analysis of legal documents, articles, and monographs was used in the study of legislation and scientific works of scientists on the research topic. With the help of this method, it was possible to comprehensively study the work of many researchers and highlight the main features of the introduction of information technology in the courts of different countries.

Furthermore, the generalization method has made it possible to combine the general provisions on information technology and the digital transformation of government and the e-court through various international legal instruments. The method of comparison allowed us to compare the role of information technology in Ukraine and abroad, which is also allowed to conduct a comprehensive study.

In addition, the method of synthesis was used to study certain regulations governing the use of information technology in the courts in order to further generalize the provisions of such regulations.

The use of the modeling method allowed to model how the relations in the field of information technologies and their use in court will be further developed and transformed and how Ukrainian and international legislation needs to be reformed so that it meets the requirements of time and social development. 


\section{Presentation of key research findings}

In modern conditions, any institutional transformation of the judiciary must take into account their information dimension as a special object of public administration and a factor that directly affects this process. The functional value of the information and legal activity of the judicial system is expressed in the expansion of the boundaries of access to justice, which actualizes the political and legal participation of the judiciary in the information space of Ukraine. The information openness of the institutions of the judiciary has a clear instrumental value in ensuring the political and legal integrity of justice in the information interaction of the state and civil society.

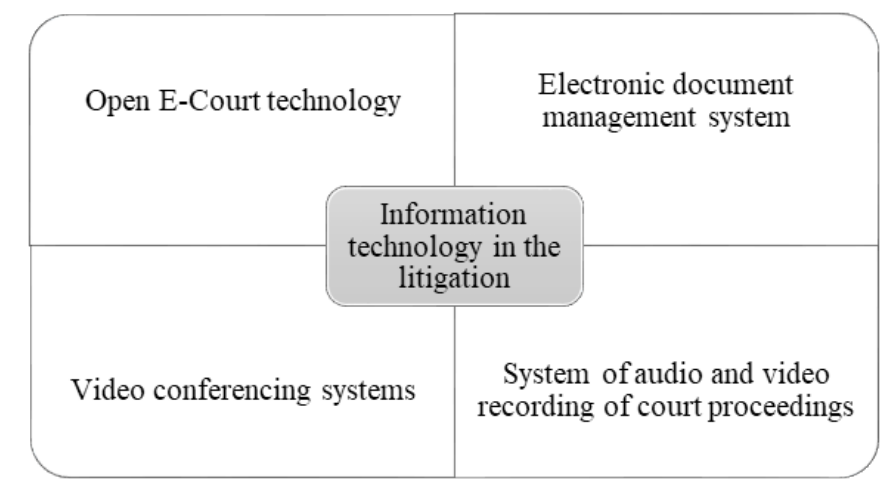

Figure 1: The groups of nformation technology in the litigation (Own creation).

The basic criteria for assessing the information openness of justice should include:

- The qualitative level of realization of the right of citizens to information about the judicial activity.

- The degree of public confidence in the judiciary and the level of authority of the judiciary in society.

- The level of ensuring the right of citizens to information about the judicial activity, and;

- The degree of satisfaction of the interests of the judicial community in the information sphere (Council of European Judges, 2011). 
Before considering the place and role of information technology in pandemic litigation, it should be studied how they are used in the courts.

Information technology in the litigation can be divided into several groups:

- Electronic document management system.

- System of audio and video recording of court proceedings.

- Video conferencing systems.

- Open E-Court technology (Figure 1).

An electronic court was launched in Ukraine during the quarantine. The Law of Ukraine "On the Judiciary and the Status of Judges" (2016) entrusts the implementation of e-justice to the State Judicial Administration of Ukraine.

However, in emergency conditions for the introduction of quarantine, remote justice in the conditions of national quarantine is not limited exclusively to the activities of the Electronic Court. The problem of participation in court hearings is solved by providing the possibility of holding a court hearing by videoconference (High Council of Justice, 2020). Thus, concerning participation in the hearing by videoconference, then during the quarantine, amendments to the procedural codes came into force, which provide for the possibility for the duration of the quarantine to participate in the hearing by videoconference outside the court using their technical means. This means that lawyers and representatives of the parties and other participants in the widowhood process will be able to participate in the meeting from their computer or telephone (Legal Bulletin of Ukraine, 2017). The use of quarantine videoconferencing is timely and necessary in quarantine and the use of such information technology in the courts should continue.

At the same time, several problems in the use of information technology do not depend on quarantine.

Thus, some audio recording and recording systems currently used in Ukrainian courts do not provide multi-channel recording, as required by international law. Records made by such systems are not protected from editing, editing and rewriting with modified content, i.e. there is a possibility of their partial or complete falsification without the possibility of verifying legitimacy.

Open Court technology is used to a rather limited extent in Ukraine. In general, the Open Court technology was created to ensure public control over the fairness of justice, a system of audio and video broadcast of the trial in real time via the Internet, which allows increasing the responsibility 


\section{Nana Bakaianova, Yurii Polianskyi y Oleksii Svyda

of judges. Directly implements the principle of publicity and openness of the trial. This technology provides the ability to view the trial online via the Internet. Used in the courts of the United States, the Russian Federation. Providing such an opportunity in Ukraine would greatly help to make the trial public.

It would not be superfluous to introduce an electronic document management system in the courts, which would allow the participants in the process to be acquainted with the case materials and submit electronic evidence without unnecessary bureaucracy.

Nevertheless, in general, the organization of information support of courts should take into account specific features, properties, forms, legal aspects of information, be able to ensure the functioning of the judicial system in terms of reform, and create conditions for improving the efficiency of the judiciary. First of all, it is necessary to take into account that the information used in court proceedings has several features: large amounts of information; repeatability of cycles of receiving and processing information in a certain sequence; a variety of information by access mode, etc. For the effective use of information technology in the judiciary, it is necessary to take into account the peculiarities of the administration of justice and the properties of information.

If we analyze the statistics on the use of information technology in the courts, it is currently as follows (Table 1, Table 2, Table 3: Figure 2; Figure $3)$.

\begin{tabular}{|c|c|c|c|c|}
\hline \multirow{2}{*}{ Types of courts } & \multicolumn{4}{|c|}{ Number of court hearings held by videoconference } \\
\cline { 2 - 5 } & \multicolumn{3}{|c|}{$\mathbf{2 0 1 8}$} & $\mathbf{2 0 1 9}$ \\
\cline { 2 - 5 } & Number & $\begin{array}{c}\text { Dynamics, } \\
\text { times }\end{array}$ & Number & $\begin{array}{c}\text { Dynamics, } \\
\text { times }\end{array}$ \\
\hline Courts of appeal & 17081 & 1,1 & 28710 & 1,7 \\
\hline $\begin{array}{c}\text { Local commercial } \\
\text { courts }\end{array}$ & 12196 & 1,4 & 15559 & 1,3 \\
\hline $\begin{array}{c}\text { Commercial } \\
\text { courts of appeal }\end{array}$ & 3528 & 1,2 & 4811 & 1,4 \\
\hline $\begin{array}{c}\text { District } \\
\text { administrative } \\
\text { courts }\end{array}$ & 7546 & 1,8 & 10859 & 1,4 \\
\hline $\begin{array}{c}\text { Administrative } \\
\text { courts of appeal }\end{array}$ & 3655 & 1,5 & 4224 & 1,2 \\
\hline Local courts & 87730 & 0,9 & 103665 & 1,2 \\
\hline Total & 131736 & 1,2 & 167828 & 1,3 \\
\hline
\end{tabular}

Table 1: The use of information technology in the courts in 2018 and 2019. Own elaboration. 
Local courts

Administrative courts of appeal

District administrative courts

Commercial courts of appeal

Local commercial courts

Courts of appeal
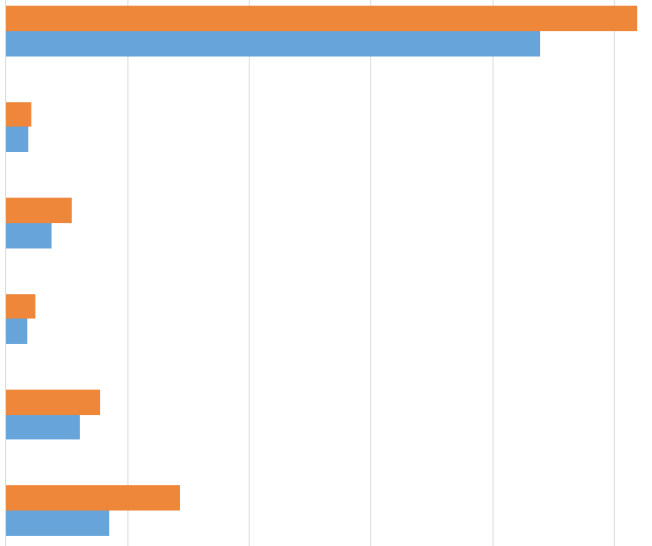

$\begin{array}{rrrrrr}0 \quad 20000 \quad 40000 & 60000 & 80000 & 100000 & 120000 \\ & \square 2019 \quad 2018 & & & & \end{array}$

Figure 2: Number of court hearings held by videoconference via Internet in 2918, 2019. Own elaboration.

The State Judicial Administration of Ukraine (2020a, 2020b) in its reports of 2019 noted that it continued to take organizational measures to provide judges of Ukraine with means of information and support of electronic documents of justice.

\begin{tabular}{|c|c|c|c|c|}
\hline \multirow{2}{*}{ Types of courts } & \multicolumn{2}{|c|}{$\begin{array}{c}\text { Informatization } \\
\text { tools, thousand }\end{array}$} & $\begin{array}{c}\text { Informatization } \\
\text { services, } \\
\text { Unousand UAH }\end{array}$ \\
\cline { 2 - 5 } & $\mathbf{2 0 1 8}$ & $\mathbf{2 0 1 9}$ & $\mathbf{2 0 1 8}$ & $\mathbf{2 0 1 9}$ \\
\hline Local courts & 135063,8 & 165642,7 & 55444,4 & 53551,6 \\
\hline District administrative courts & 21509,6 & 27363,4 & 11993,7 & 16460,3 \\
\hline Local commercial courts & 15757,3 & 20398,4 & 6054,3 & 10335,3 \\
\hline Courts of appeal & 35301,0 & 21408,8 & $\mathbf{2 5 5 4 0 , 2}$ & $\mathbf{2 0 0 7 6 , 8}$ \\
\hline Administrative courts of appeal & 12962,4 & 7705,4 & 6947,5 & 7971,5 \\
\hline Commercial courts of appeal & 5683,5 & 4495,0 & 2680,8 & 3764,3 \\
\hline Total & $\mathbf{2 2 6 2 7 7 , 6}$ & $\mathbf{2 4 7 0 1 3 , 7}$ & 108660,9 & 112159,7 \\
\hline
\end{tabular}

Table 2: Costs of providing courts with information facilities in 2018 and 2019. Own elaboration. 


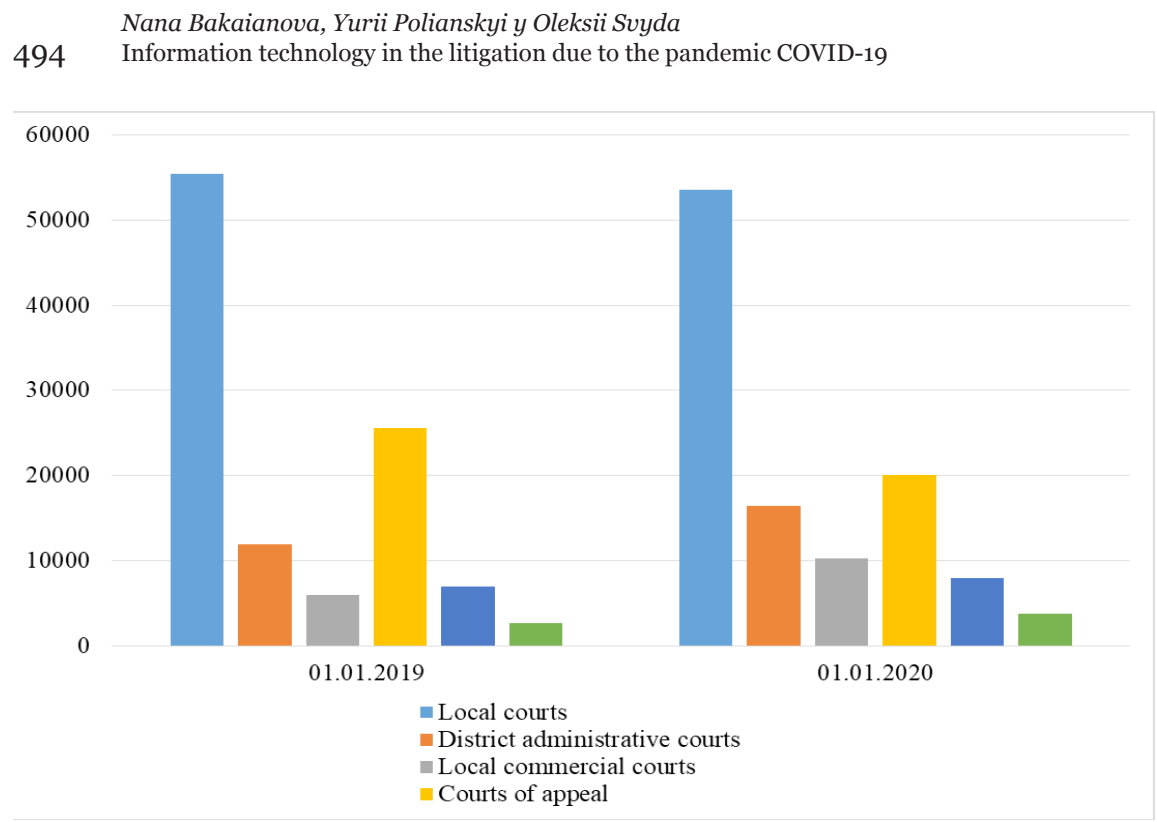

Figure 3: Costs of providing courts with information facilities in 2019 and 2020. Own elaboration.

\begin{tabular}{|c|c|c|c|}
\hline \multirow{2}{*}{ Types of courts } & \multicolumn{3}{|c|}{ Total } \\
\cline { 2 - 4 } & $\mathbf{2 0 1 8}$ & $\mathbf{2 0 1 9}$ & Dynamics, \% \\
\hline Local courts & 190508,2 & 219194,2 & 15 \\
\hline District administrative courts & 35503,3 & 43823,7 & 23 \\
\hline Local commercial courts & 21811,6 & 30733,7 & 41 \\
\hline Courts of appeal & 60841,2 & 41485,6 & -31 \\
\hline Administrative courts of appeal & 19909,9 & 15676,9 & -21 \\
\hline Commercial courts of appeal & 8364,3 & 8259,3 & -1 \\
\hline Total & 336938,5 & 359173,4 & 7 \\
\hline
\end{tabular}

Table 3: The Dynamics costs of providing courts with information facilities in 2018 and 2019. Own elaboration.

Statistical data confirm that every year information technologies are used more and more in the courts of Ukraine (Table 1). This is manifested both in the increase in the allocation of funds for this area (Table 2, Table 3) and the increase in the use of electronic justice and information technology in justice.

Now, let's pay attention to how information technologies are used in courts in different countries of the world. 
For example, in the United Kingdom, the Grand Court of England has begun testing the possibility of holding all meetings by video conference using the WT MeetMe application, a video conference called Skype for Business.

In the Republic of Lithuania, there is a service with which you can submit procedural documents online. In Australia, it is also planned to conduct court proceedings by videoconference using Skype, etc.

In the United States, there is an electronic court system with free access, through which it is possible to obtain information about the court document, read the register of applications, study the progress of the case and the history of decisions, as well as view the calendar of scheduled hearings (The introduction of it-technologies in the judiciary is one of the ways of transparent court activity, 2017).

Thus, both in Ukraine and in the world, despite many problematic issues, information technology is playing an increasingly important role in the judiciary. Quarantine has become a so-called test for the judiciary, which has made it possible to understand how adaptive Ukrainian courts are and capable of change in difficult times.

\section{Conclusions}

- Under quarantine conditions, all countries have begun to take active steps to meet the information support of courts, but only the full implementation of these steps will significantly increase the transparency of courts, reduce litigation, increase accountability of judges and court staff, and will allow organizing at the appropriate level the process of acquainting the parties with the case materials, etc.

- The following notes were drawn during the study.

1. The use of information technology improves access to justice and increases its efficiency and transparency of mechanisms for its implementation.

2. There is a need for further unification of computer technology to automate litigation.

3. Whether quarantined or not, information technology in courts should serve as a tool or means of improving the administration of justice, facilitating users' access to courts and strengthening the guarantees established by the Convention - access to justice, impartiality, judicial independence, fairness and 
reasonable time for the consideration of the case.

4. The introduction of Internet technologies in the judiciary should not harm the authority of the judicial system.

5. It is important to ensure that in case of failure of the "e-court" there will be alternative solutions (backup e-mail address, etc.)

6. Not all people have access to information technology (retirees, low-income people, etc.), so traditional means of accessing information should remain.

7. It should not be forgotten that in the case of online litigation or the development of online platforms for autonomous court decisions, it is necessary to take into account the interests of the parties and ensure compliance with their procedural rights (to present evidence, call witnesses, etc.).

8. It is necessary to conduct legal education work to disseminate information about the possibilities of electronic justice because often people do not use electronic services just because they do not know about their availability and functionality.

9. It is important to establish the protection of databases and information contained in the electronic mode at different levels of security. This can be achieved by using various remote servers and restrictions on the access of court staff and enshrining such restrictions at the legislative level.

10. The introduction of information technology helps and will further save citizens and the state budget by reducing the cost of paper, postage, etc.

11. It is necessary to ensure a dialogue between technology developers and those responsible for litigation. Regardless of which body is responsible for the management of information technology, it is important to ensure the participation of judges in the decision-making process regarding the use of such technology.

- Thus, the introduction of information technology in the judiciary is a necessity and requirement of today and it is one of the ways to ensure transparent court activities and guarantee access to justice because these technologies help bring the court closer to the citizen. In particular, the need to use information technology in the judiciary has become more acute during quarantine restrictions, when people are in real danger of not being able to physically submit documents and participate in court proceedings, as several restrictions on the administration of justice have been imposed. 
- Moreover, even taking into account the many positive steps taken by Ukraine to introduce information technology in the courts, the research topic requires further research. Thus, it is necessary to dwell on the analysis of the possibility of using and implementing online platforms for online litigation and to develop methods of informatization and the right to educate citizens about the possibilities of applying to the court electronically.

\section{Bibliographic References}

BABYAK, N.V. 2016. "Status and problems of information and analytical support of the administrative courts of Ukraine" In: Scientific Bulletin. Vol. 3. pp. 124-134.

CABINET OF MINISTERS OF UKRAINE. 2020. On prevention of the spread of coronavirus Covid-19 on the territory of Ukraine: Resolution 211. Available online. In: https://www.kmu.gov.ua/npas/pro-vnesennyazmin-do-postanovi-kabinetu-ministriv-ukrm020420ayini-vid-11bereznya-2020-r-211. Consultation date: 12/12/2019.

CONSTITUTION OF UKRAINE. 1996. Law, no. 254k / 96-VR. Revision of September 30, 2016, grounds - 1401-19. Available online. In: https:// zakon.rada.gov.ua/laws/show/254\%Do\%BA/96-\%Do\%B2\%D1\%80. Consultation date: 12/12/2019.

COUNCIL OF EUROPEAN JUDGES. 2011. Judiciary and Information Technology: Opinion, no. 14. Available online. In: https://vkksu.gov. ua/userfiles/doc/perelik-dokumentiv/EU_Standarts_book_web-1.pdf. Consultation date: 01/22/2020.

COUNCIL OF JUDGES OF UKRAINE. 2020. Letter, no 9 pc-186/20/. Available online. In: http://rsu.gov.ua/uploads/news/nogrs-18620-vid16032020-verhovn-92b86c6546.pdf. Consultation date: 12/12/2019.

DEVELOPMENT OF LEGAL REGULATION OF RELATIONS ON THE INTERNET: CHALLENGES AND TRENDS. 2017. E-court - the current state and ways to improve. Available online. In: https://ndipzir.org.ua/ wp-content/uploads/2017/07/Yefremova/4_3.pdf. Consultation date: $12 / 12 / 2019$.

EUROPEAN CONVENTION ON HUMAN RIGHTS. 1950. Convention for the Protection of Human Rights and Fundamental Freedoms. Available online. In: https://www.echr.coe.int/documents/convention_eng.pdf. Consultation date: 12/02/2019. 
Nana Bakaianova, Yurii Polianskyi y Oleksii Svyda
498 Information technology in the litigation due to the pandemic COVID-19

FISUN, V.; KOSTRIKOVA, E. 2020. Quarantine proceedings. Legal newspaper online. Available online. In: https://yur-gazeta.com/publications/ practice/inshe/karantinne-sudochinstvo.html. Consultation date: 01/10/2020.

GRYGORENKO, Yu. 2020. Functioning of the subsystem "Electronic Court". About ESITS and the court by videoconference. Website of the National Bar Association of Ukraine. Available online. In: https://unba.org. ua/publications/5453-funkcionuvannya-pidsistemi-elektronnij-sudpro-esits-ta-sud-u-rezhimi-videokonferencij.html. Consultation date: 01/10/2020.

HIGH COUNCIL OF JUSTICE. 2020. On access to justice in the context of the SARS-CoV-2 coronary virus pandemic of acute respiratory disease Covid-19: Decision. Available online. In: https://court.gov.ua/press/ news/916824/. Consultation date: 12/02/2019.

HREVTSOVA, Radmyla Yu. 2020. "Institutional and legal aspects of health care in times of covid-19: learning from the Ukrainian experience" In: Medicine and Law. World Association for Medical Law. Vol. 39, No. 2, pp, 333-350.

LAW OF UKRAINE. 2000. On protection of the population from infectious diseases, No. 1645-III. Available online. In: https://zakon.rada.gov.ua/ laws/show/1645-14. Consultation date: 12/02/2019.

LAW OF UKRAINE. 2016. On the Judiciary and the Status of Judges, no. 1402VIII. Available online. In: https://zakon.rada.gov.ua/laws/show/140219. Consultation date: 12/02/2019.

LAW OF UKRAINE. 2020. On Amendments to the Law of Ukraine "On Protection of the Population from Infectious Diseases" to Prevent the Spread of Coronavirus Disease (Covid-19), no. 555-IX. Available online. In: https://zakon.rada.gov.ua/laws/show/555-20. Consultation date: 12/02/2019.

LEGAL BULLETIN OF UKRAINE. 2017. Information technologies in litigation. Available online. In: https://yvu.com.ua/informatsijni-tehnologiyi-usudochynstvi/. Consultation date: 01/10/2020.

MOROZ, I.Y. 2020. Information support in the courts of Ukraine. Internet conference of the department of information technologies of NU "OLA". Available online. In: http://conf.inf.od.ua/doklady-konferentsii/138moroz. Consultation date: 12/02/2019.

PETRENKO, V.S. 2018. "Information technologies in litigation" In: Civil law, Vol. 26, pp. 74-76. 
STATE JUDICIAL ADMINISTRATION OF UKRAINE. 2020b. Report on the activities of the Judicial Administration of Ukraine in 2019. Available online. In: https://hcj.gov.ua/sites/default/files/zvit_dsa_2019.pdf. Consultation date: $01 / 10 / 2020$.

STATE JUDICIAL ADMINISTRATION. 2018. On testing the subsystem "Electronic Court" in local and appellate courts began operation of the subsystem "Electronic Court" in test mode: Order. Available online. In: https://dsa.court.gov.ua/userfiles/media/628_18.pdf. Consultation date: $01 / 10 / 2020$.

STATE JUDICIAL ADMINISTRATION. 2020a. High Council of Justice the Report on the Activities of the State Judicial Administration of Ukraine in 2019. Available online. In: https://hcj.gov.ua/news/golova-dsaukrayiny-predstavyv-vyshchiy-radi-pravosuddya-zvit-pro-diyalnistderzhavnoyi. Consultation date: 01/10/2020.

THE INTRODUCTION OF IT-TECHNOLOGIES IN THE JUDICIARY IS ONE OF THE WAYS OF TRANSPARENT COURT ACTIVITY. 2017. Law and Business. Available online. In: https://zib.com.ua/ua/print/24017uprovadzhennya_it-tehnologiy_u_sudoviy_sistemi_odin_zi_shly. html. Consultation date: 01/22/2020.

TURKINA, I. 2011. Information technologies in the judicial system. State and society. Available online. In: http://www.kbuapa.kharkov.ua/e-book/ putp/2011-3/doc/4/05.pdf. Consultation date: 01/10/2020.

VAIVALA, G.V. 2016. "Information technologies of communications between the court and participants in the trial, between the court and other government agencies" In: Law and information society. Vol. 1 (6), pp. 101-106. Available online. In: http://apir.org.ua/wp-content/ uploads/2016/07/Vaivala6.pdf. Consultation date: 12/02/2019.

VENICE COMMISSION - OBSERVATORY ON EMERGENCY SITUATIONS. 2020. Available online. In: https://www.venice.coe.int/files/ EmergencyPowersObservatory//T11-E.htm. Consultation date: 12/02/2019.

YELTSOV, V.O. 2010. The essence of information support of courts. Law Forum. Available online. In: http://dspace.univd.edu.ua/xmlui/ bitstream/handle/123456789/3384/Sutnist\%20informatsiinoho\%20 zabezpechennia\%20_Yeltsov\%20_2010.pdf?sequence=1\&isAllowed=y. Consultation date: $01 / 10 / 2020$.

ZAPOROZHCHENKO, O. 2020. Judicial proceedings during quarantine: case law on procedural issues. Liga Zakon. Available online. In: https:// jurliga.ligazakon.net/ua/news/194690_sudochinstvo-pd-chaskarantinu-sudova-praktika-z-protsesualnikh-pitan. Consultation date: 01/10/2020. 

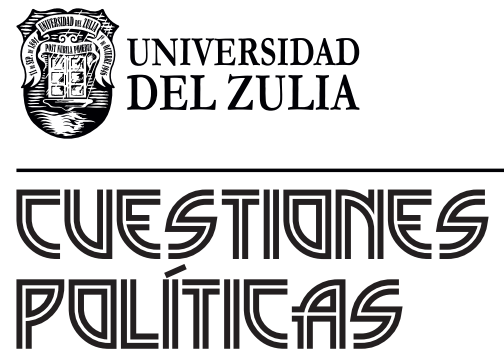

Vol.38 NEspecial

Esta revista fue editada en formato digital y publicada en diciembre de 2020, por el Fondo Editorial Serbiluz, Universidad del Zulia. Maracaibo-Venezuela 